\title{
DE HERMENEUTISCHE THEOLOGIE VAN H. M. KUITERT
}

Dr. R. Bremmer

\section{DR. H. KUITERT ALS THEOLOOG}

Harry Kuitert is een leerling uit de school van G. C. Berkouwer. Hij promoveerde bij hem in 1962 op een dissertatie over de mensvormigheid Gods. Hij is thans hoogleraar in de ethiek aan de Vrije Universiteit en maakte eerder naam als studentenpredikant te Amsterdam.

Kuitert is een vruchtbaar publicist. Naast zijn dissertatie uit 1962 vallen te noemen "De realiteit van het geloof" (1966), „Verstaat gij wat gij leest?" (1968), "Zonder geloof vaart niemand wel" (1974) en „Wat heet geloven?", zijn laatste boek uit 1977. In „Anders gezegd" (1970) en „Om en om" (1972) bundelde hij artikelen en lezingen op dogmatisch en ethisch terrein. We hebben in Kuitert met een vruchtbaar en geëngageerd publicist te doen. Zijn boeken beleven vele drukken en voorzien blijkbaar in een behoefte. Ze zijn in het algemeen erg helder geschreven en boeiend te lezen. Kuitert stelt aan de orthodoxie vaak lastige vragen waar we ons niet met een handomdraaien vanaf kunnen maken. Ze dwingen ook om door te denken over de vraag hoe wij het geloofsbezit van de Gereformeerde Kerk dat zij uit de tijd van de Reformatie heeft ontvangen, kunnen verwoorden in de taal van deze tijd en toepassen op de problemen van onze tijd.

We willen eerst iets zeggen over het grondmotief van Kuiterts denken, wat hem beweegt. Wij hebben dat tot uitdrukking gebracht in de titel: Kuiterts hermeneutische theologie. Daarna handel ik over de concretisering daarvan in wat ik zou willen noemen zijn verschillende projecten. Daarbij valt een duidelijke verschuiving van belangstelling te constateren van theologische naar godsdienstwijsgerige vragen.

\section{HET GRONDMOTIEF VAN KUITERT}

Kuitert is voor alles een hermeneutisch theoloog. Daarmee staat hij midden in de actualiteit van de theologie van de laaste decennia. De hermeneutiek houdt zich immers bezig met de vraag hoe wij de Heilige Schrift moeten uitleggen. Ze was aanvankelijk dus een hulpwetenschap voor de exegese. Maar ze is niet bij louter exegetische kwesties gebleven. Het gaat haar thans vooral om de vraag hoe de inhoud van de Bijbel en het spreken van de Bijbel toepasbaar is op en hanteerbaar voor de mens van de twintigste eeuw. Er is een sterk kerygmatisch-homiletische tendens in het vak gekomen. Hoe kunnen we de boodschap van de Bijbel zo uitleggen dat hij bij de mens van de twintigste eeuw overkomt en hem iets doct? Is de boodschap van de Bijbel nog te verkondigen in de door de natuurwetenschappen bepaalde leefwereld van deze mens? De vraag die Kuitert als titel aan zijn boekje uit 1968 „Verstaat gij wat gij leest?" meegaf, is een voluit hermeneutische vraag. 
Vooral in Duitsland zijn de discussies over de hermeneutiek opgelaaid sinds de tweede wereldoorlog. In het hartje van die oorlog, in 1941, publiceerde Rudolf Bultmann voor het eerst zijn ontmythologiseringsprogramma dat eigenlijk tot nu toe de discussies beheerst. De Bijbel en vooral het Nieuwe Testament waarvoor Bultmann zich bijzonder interesseert, spreekt in "mythologische Rede", d.w.z. in de taal en de voorstellingen van die tijd: maagdelijke geboorte, opstanding uit de doden, wonderen. Daar kun je bij de mens van deze tijd niet meer mee aan komen, die de knoppen van radio en TV bedient en als hij ziek is, zich in een modern ziekenhuis laat verplegen. De wonderlijke geboorte van godenzonen en terugkeer uit de dood hoort bij de wereld van toen. De wereld van nu kan dat niet meer geloven. Dat hoeft ook niet vindt Bultmann, want het Nieuwe Testament is zelf al bezig zichzelf te ontmythologiseren. Zo laat het Johannesevangelie ons zien dat het hellenistisch-gnostische en joods-apokalytische mythologisch materiaal waarvan het zich bedient, doorkruist wordt al door de eschatologische boodschap van Jezus die dat materiaal op een eigen wijze gebruikt en interpreteert. Het Nieuwe Testament en vooral het kerygma van Jezus gebruikt dit materiaal om ons de bevrijdende liefde van Jezus te prediken die de mens verlost van zijn onvrijheid en gebondenheid aan de wetmatigheid van deze wereld en hom in de vrijheid van de vergeving stelt en van het kindschap. We moeten daarom niet proberen die mythologische spraak uit het evangelie te schrappen maar met behulp ervan de mens van heden het evangelie verkondigen.

We kunnen ook niet achter het spreken van het Nieuwe Testament teruggaan om de historische Jezus te vinden. Dat is onnodig en onmogelijk. Het geloof richt zich op het Woord en niet op de historisch-registreerbare feiten er achter.

Fuchs en Ebeling, Bultmann's leerlingen, zijn het daarmee niet eens. $\mathrm{Zij}$ vinden dat wij ons best voor de historische Jezus mogen interesseren. Terecht zegt Heinrich Ott dat in Bultmanns theologie motieven van de oude liberale theologie met haar scherpe kompromisloze Bijbelkritiek met die van de nieuwere dialectische theologie tot een nieuwe eenheid zijn verbonden.

Het is deze problematiek die Kuitert vanaf het begin in haar greep heeft en waarop hij vanuit het startpunt van de gereformeerde theologie een antwoord probeert te vinden. Is hem dat gelukt? Heeft hij daarin de gereformeerde theologie verder gebracht? Is zij bij hem tegen deze vragen opgewassen? Dat wil ik in dit referaat aan de orde stellen.

\section{HET ANTROPOMORFE SPREKEN GODS}

Hoezeer deze kwesties hem in haar greep hebben, blijkt al uit zijn dissertatie uit 1962. Daarin stelde hij het antropomorfe spreken van de Bijbel over God aan de orde, een hermeneutisch vraagstuk van de eerste orde. De bijbel spreekt immers over God als ware Hij een mens. Ze spreekt van Gods hand, zijn machtige armen die de vromen beschermt, zijn ogen die de hele wereld doorlopen, zijn 
oor dat hoort wie tot Hem roept. Ze spreekt zelfs van Gods ingewanden, Jer. $31: 20$ : daarom rommelt mijn ingewand over hem (Israel). Ik citeer de Statenvertaling, want de Nieuwe Vertaling heeft: daarom is mijn binnenste over Hem ontroerd. Daaruit blijkt dat een vertaling altijd een stukje uitleg is. De Nieuwe Vertaling heeft het antropomorfisme weggewerkt.

De christelijke kerk heeft deze antropomorfismen nooit letterlik genomen. Ze heeft die altjid uitgelegd en daarbij in rekening gebracht dat God God is en geen mens. Calvijn noemde dat antropomorfe spreken door God accommodatie aan de bevatting van de mens. God houdt rekening met onze menselijke bevatting. Zoals een vader dat doet wanneer Hij tot zijn kinderen spreekt. Vooral $\mathbf{K}$. Schilder heeft in zijn dissertatie sterke nadruk gelegd op clat accommoderend spreken Gods.

Kuitert verwerpt deze uitleg. Hij is van oordeel dat achter dat niet letterlijk nemen van het antropomorfe spreken Gods een opvatting ligt van het wezen Gods die zich niet met de Schrift verdraagt. God wordt dan opgevat als een onveranderlijk zijn. Die visie op Gods wezen heeft de latere theologie overgenomen uit de aristotelische-thomistische theologie van de Middeleeuwen. De Bijbel spreekt volgens Kuitert niet over een transcendente God en daarom mogen wij dit spreken Gods niet vanuit zijn transcendentie benaderen. God is geen transcendente majesteitelijke God die boven de schepping is verheven. Hij is onze bondgenoot. De notie van het verbond als omgangsvorm van God met de mens, staat in zijn eerste geschriften hoog genoteerd. „De enige, echte, ware God is de Partner-God van Israel" (233). Later zwakt dat spreken over God als bondgenoot wat bij hem af.

Wij moeten daarom God nemen zoals Hij Zich aandient. We mogen het mensvormige spreken van de Schrift over God niet van zijn aanstotelijkheid ontdoen. Kuitert wil dit zo kras mogelijk nemen. De bijbelschrijvers, aldus Kuitert, ,hebben een dermate konkrete gestalte van Jahweh voor ogen, dat daarbij ingesloten is, wat wij vandaag het lichamelijke zouden noemen" (215). In zijn latere geschriften is hier niets van terug te vinden. Dan komt God vooral naar voren als macht en als liefde. Wel blijft gehandhaafd dat wij God alleen kunnen kennen in zijn geschiedenis met de mensen. Hij bestaat voor Israel niet in zichzelf, in zijn aseitas, afgedacht van zijn woorden of daden. „De verhouding tot de mens hoort wezenlijk bij het God-zijn van God" (265).

Het Partner-Bondgenoot zijn van God bereikt zijn climax in Jezus van Nazareth. De vleeswording van het Woord is een totaal nieuw punt in de omgang van God met de mens. God neemt in Jezus de rol van de ontrouwe bondspartner op Zich. In Jezus is God gewoon verschenen. We moeten niet spreken van een verberging van de heerlijkheid Gods achter en in Jezus' menselijke natuur. Dan is er toch weer sprake van een transcendente heerlijkheid van Gods eeuwige Zoon. Er valt niets te verbergen, want er is geen transcendentie.

Daarom moeten wij in de leer van de schepping niet filosoferen over een analogie tussen God en mens. God schiep de mens naar 
zijn beeld. „De echte mens is de theomorfe mens, d.w.z. de mens die bondgenoot is in zijn handelen en spreken en juist daarin de gelijkenis met God vertoont". Aan de antropomorfe God beantwoordt de theomorfe mens (281). De Israelitische mens is theomorf.

Hoe moeten wij dit opvatten? Hier stelt Kuitert voor het eerst de vraag: verstaat gij wat gij leest? Hoe moet de moderne mens dit Israelitisch sprekende Oude Testament verstaan? Kuitert zegt dat hij beslist niet de weg van Bultmann wil gaan. Van een scheiding tussen ,israelitische-kulturele omkorsting en goddelijke boodschap" wil Kuitert nu nog niet weten (295). Er mag zelfs geen scheiding worden gemaakt en Kuitert spreekt nu weer krasse taal tussen ,archeologie (eventueel ethnologie) en kerygma" (294). „Extrapolatie van het israelitische uit het bijbels getuigenis is niet alleen onmogelijk maar theologisch gesproken ook ongeoorloofd" (296). Er zit volgens Kuitert in zijn dissertatie maar één ding op: we moeten ons gewoon bekeren tot het Israëlitisch spreken van het Oude Testament! Daarbij moet de theologie ons, gojim, heidenen, helpen!

De moeilijkheid waarin Kuitert zichzelf bij zijn uitleg van het Oude Testament heeft gebracht door het antropomorfe spreken over God letterlijk te nemen, en God lichamelijk te achten, lost hij dus op door dit spreken Israelitisch te verklaren en de theologie de taak te geven ons tot dit Israelitisch spreken te bekeren. Reeds hier krijgt de theologie bij hem een bijzonder belangrijke taak in het verstaan van de Schrift.

\section{HET „HISTORISCHE” I.P.V. HET ISRAELITISCHE}

In zijn tweede boek „De realiteit van het geloof” uit 1966 pakt hij de zaak van een heel andere kant aan. We horen nu nauwelijks meer iets over de mensvormigheid Gods en het Israelitisch spreken van de Schrift. Kuitert confronteert zich nu in dit tweede boek met de theologie van Bultmann en zijn leerlingen. Het sleutelwoord is nu niet langer het Israelitisch spreken maar het historische. Dat zal van nu af aan een grote rol in zijn geschriften spelen.

Zijn uitgangspunt is nu dat de christelijke kerk in de bijbel „het overgeleverde geloofsgoed" mee heeft gekregen in haar gang door de eeuwen. Kuitert noemt dat het ,traditum”. Hij bedoelt daarmee het bijbels getuigenis in wat hij omschrijft als zijn ,,brutototaliteit". Vráág: wat is dan het netto van dit getuigenis? Het Israelitisch-joodse karakter van de bijbelse overlevering noemt hij nu ,de historiciteit van het bijbelse spreken" (165). De kennis Gods is "historisch geformuleerd". Daarom staat de bijbel ook open voor het historisch-kritisch onderzoek. De resultaten daarvan vormen, aldus Kuitert, zelfs ,het enige echte probleem waarmee het christelijk geloof geconfronteerd kan worden" (162).

Hoe komt nu dit historisch geformuleerde bijbels getuigenis over tot ons mensen van de twintigste eeuw? Kuitert spitst deze vraag nu niet slechts toe op het antropomorfe spreken van de Schrift maar op héél het bijbels getuigenis.

Hij verwerpt daarvoor de oplossing van Bultmann. In de exis- 
tentietheologie is het „Vorverstännis” van de mens als een existentieel wezen tot een filter geworden voor het verstaan van de Schrift. Alleen wat de mens aanspreekt op zijn existentieel bestaan is dan in de boodschap van de Schrift relevant. Die kant wil hij niet uit.

Waarom spreekt het bijbels getuigenis ons aan? Alleen omdat het daarin gaat om de gebeurtenissen rond Jezus. Daarin ligt voor hem in zijn tweede boek de kern van de zaak. In wat zich afspeelde rond Jezus komen wij zélf ter sprake en komt God ter sprake. De gebeurtenissen rond Jezus vormen de „harde kern" van het historisch bijbels getuigenis.

Vanzelf doet zich nu de vraag voor waar de grens ligt tussen het brutobijbels getuigenis en het netto, in casu de gebeurtenissen rond Jezus. Daarvoor onderscheidt Kuitert nu tussen het openbaringsgetuigenis aan de ene kant en die culiurele ruinte, warin het geklonken heeft, aan de andere kant. Het eerste noemt hij „die Sache" en het tweede de verpakking. In zijn dissertatie wilde hij zelfs geen onderscheid maken tussen kerygma en archeologie, nu wil hij dat dus wél. Hoewel: het blijft wat tweeslachtig: wij kunnen „vanwege de onlosmakelijke verbondenheid waarin getuigenis en klankbodem, - of ook ,Sache en verpakkingsmateriaal ons vanuit de eigen aard van Gods openbaring ons gegeven zijn, wel in grote lijnen maar nooit helemaal precies tussen het één en het ander onderscheiden" (185). Hier zal de christelijke kerk met voorzichtigheid en ",begeleid door noeste theologische arbeid" haar weg mocten gaan. Wéér krijgt de theologie een centrale taak: het loswikkelen van de "Sache" uit de verpakking.

Ik laat nu rusten wat hij in 1968 schreef in ,Verstaat gij wat gij leest?" Dit zal in deze kring overbekend zijn. Speciaal het standpunt dat hij innam in dit en in andere geschriften over Gen. 1-3. Ik vervolg nu met de scherpe wending die zijn denken nam.

In zijn geschrift uit 1968 ,Verstaat gij wat gij leest?” borduurt Kuitert op dit thema door. Hij onderscheidt nu tussen gebeurtenissen in de bijbel waarvan het gebeurteniskarakter ons wél en andere waarbij ons dat gebeurteniskarakter ons "minder wordt opgedrongen" (of helemaal niet). De laatste reeks komt vooral voor in het Oude Testament. Kuitert rangschikt daaronder o.a. de drijvende bijl van Elisa, Jona in de vis (een midrasj). Er is één gebeurtenis waarvan het gebeurteniskarakter ons met zoveel woorden verteld wordt: de geschiedenis van Jezus' kruis en opstanding (78). Dat is zo'n uniek gebeuren dat daarvoor het historisch-kritisch onderzoek halt moet maken.

Maar wel hoort tot de kennisbagage van de Schrift, de verpakking stellig de scheppingsgeschiedenis uit Genesis $1-3$. Die is zeker niet in haar gebeurteniskarakter zoals de bijbel het vertelt op te vatten. Wat deze hoofdstukken ons ook te melden hebben ,in ieder geval niet dat de wereld ongeveer 6000 jaar oud is en dat in die eerste prille, reeds op maat gemaakte wereld, een eerste mensenpaar woonde" (76). Genesis $1-3$ verschaft ons geen ,inlichtingen over de wordingsgeschiedenis van mens en wereld" (77). De oudste mensheid was immers een primitieve mensheid, „eerder een hordewezcn dan een zo fijn besnaard wezen als Adam van Genesis" (25). 
Wel moeten we die hoofdstukken niet uit de bijbel schrappen. Ze vormen een onopgeefbaar onderdeel van de heilsboodschap van de Schrift. Ze blijven ons Israels God als Schepper verkondigen „ook als wij deze eerste hoofdstukken als leermodel in plaats van als een verhaal van echte gebeurtenissen hebben leren zien" (77). Adam dient in Romeinen 5 alleen als een leermodel om ons de unieke plaats van Christus te belichten. Er verandert niets aan ons geloof zegt Kuitert, ,als Adam niet een historische persoon blijkt te zijn" (28).

Kuitert sprak zo niet voor het eerst over Genesis 1 tot 3 . In 1963, op een landdag voor de Vereniging van (christelijke) Natuuren Geneeskundigen had hij deze visie ook al geboden. Hij nam ze op in de bundel "Anders gezegd" van 1970. Daar ging hij breder op de kwesties rond Genesis 1 tot 3 in. Israel, zo betoogde hij toen, heeft de stof van de scheppingsgeschiedenis ontleend aan de scheppingsverhalen van de volken rondom. Het heeft het spreken van die volkeren over een oerchaos en over goden die daar scheppend mee bezig zijn, zo geinterpreteerd dat hun materiaal nu dienstbaar wordt aan de verkondiging van Israels God als Schepper. Israel heeft vanuit zijn belijden van God als Bondsgod en Bevrijder geconcludeerd tot God als Schepper. De schepping is geloofsconclusie uit het Bondsgod zijn van God. De God van Israel is Koning en beheerst de chaos. Hij is macht, een thema dat tot in Kuiterts laatste geschriften voorkomt.

Is God dan toch transcendent? Staat $\mathrm{Hij}$ dan toch boven het geschapene? Is Hij dan toch veel méér dan zijn partner, de mens? Is Gods Schepper zijn los te maken van zijn transcendentie? Israel, aldus Kuitert, heeft aan de verhalen van de volkeren, ,polemisch en doxologisch net zo lang gebogen en gewrikt totdat het een verhaal (daarom een verhaal!) geworden was, dat paste bij deze God, Israels God, de God van het bondgenootschap, die de wereld niet tot een tohoewabohoe heeft geschapen zoals het bij Jesaja heet (Jes. 45:18) maar tot een behuizing voor zijn menselijke bondgenoot" (Om en om 25). Aan die verwerping van Genesis 1 tot 3 als gebeurtenis zit voor Kuitert ook vast de verwerping van de dood als straf op de zonde. De dood is een biologisch gegeven dat bij het mens zijn hoort. Mensen moeten sterven en plaats maken voor anderen. Pas Paulus spreekt over de dood als een gericht Gods. Hij interpreteert de dood zoals de geschiedenis van de zondevloed de regenboog tot teken van Gods verbond maakt.

Het spreekt vanzelf dat deze visie op Genesis 1 tot 3 ertoe leidde dat er ongerustheid ontstond over de vraag of Kuitert nog wel de historiciteit van de zondeval vast hield. Het door de synode van de Geref. Kerken (synodaal) ingestelde deputaatschap voor een gesprek met prof. Kuitert over deze kwesties, kwam in meerderheid tot de conclusie dat bij prof. Kuitert ,de belijdenis dat God de mens goed geschapen heeft en dat heel de mensheid van de aanvang van haar geschiedenis af door moedwillige ongehoorzaamheid van God vervreemd is, niet ondergraven wordt door de ontkenning van de historiciteit van de zondeval. Het is mogelijk", zo gaan deze deputaten verder, „dat sommigen hier van een inconsequentie in 
Kuiterts theologie willen spreken. Maar dat mag", aldus deputaten, „,niemand de ernst in twijfel doen trekken waarmee prof. Kuitert aan de bovengenoemde belijdenis vasthoudt, van haar onaantastbaarheid spreekt". Een minderheid bestaande uit dr J. Schelhaas en drs A. W. Meeder dacht daar anders over. Zij achtten het gesprek vastgelopen „op een zo fundamentele kwestie als de historiciteit van de zondeval".

\section{DE VERHOUDING OPENBARING EN GELOVEN EN BARTH}

Tot nu toe had vooral Bultmann en de existentietheologie Kuitert gefascineerd en had hij geprobeerd daar tegenover een positie in te nemen. Het resultaat hebben we boven gezien. $\mathrm{Er}$ kwam een scherpe onderscheiding tussen "Sache" en verpakking, tussen openbaringsgetuigenis en culturele klankbodem. Er is verskil tussen het bruto van de Schrift en het netto. Genesis 1 tot 3 sneuvelde in ieder geval als behorende tot het netto. De harde kern van de Bijbel ligt vooral in Israels Credo van God als Bevrijder en uitleider uit Egypte en vooral in de verhalen rond Jezus.

$\mathrm{Na} 1970$ neemt Kuiterts theologische arbeid een scherpe wending. Het gaat hem nu niet zo zeer meer om direct hermeneutische vragen maar om de vraag naar de verhouding van openbaring en Heilige Schrift, openbaring en geloven.

Er komt in zijn denken nu een nieuwe categorie aan de orde die een uiterst belangrijke rol gaat spelen. $\mathrm{Na}$ het Israelitisch spreken en het historische traditum wordt nu ervaring het sleutelwoord in zijn theologisch denken. De versiaanbaarheid en aanvaardbaarheid van het Schriftgetuigenis wordt nu gekoppeld aan het begrip openbaring. Daarbij kiest Kuitert, en dat is interessant, meer en meer positie tégen de theologie van Karl Barth. Er komt nu ook een nieuwe theologische ster aan zijn hemel nl. de Duitse theoloog Wolfhardt Pannenberg die zich in de Duitse theologie steeds meer opstelde tegen Barth en zijn school en die min of meer Hegeliaans beinvloed is en het geschiedenisdenken een belangrijke plaats in zijn theologie schenkt.

Het eerste merken we deze wending op in Kuiterts studie „Waarheid en verificatie in de dogmatiek" (1972). Het is de tekst van een viertal colleges die Kuitert hield voor de NCRV microfoon en die hij opnam in de bundel „Om en om" van hetzelfde jaar. Het gaat Kuitert daarin vooral om de gezagsvraag bij de Schrift. Is de Schrift voor ons kriterium van onze geloofskennis? Hoe controleren wij de juistheid van onze geloofsuitspraken? Wáár rusten die op? Zijn de is-zinnen, waarin het christelijk geloof zich uitdrukt, voor controle vatbaar? De christelijke leer dienst zich aan als een serie beweringen: is controle daarop mogelijk? En: wat is het criterium waaruit gecontroleerd wordt?

Het is duidelijk dat Kuitert de controle van de waarheidswaarde van de christelijke geloofsuitspraken niet wil laten gebeuren vanuit de Bijbel. Die heeft als laatste maatstaf voor hem haar gezag door de voorgaande projecten verloren. In plaats van de Bijbel als laatste maatstaf komt nu de wetenschap van de theologie. Ze hád al een 
grote plaats bij Kuitert, ze krijgt nu nog een grotere. Na 19 eeuwen van traditie kunnen we het zonder haar begeleiding niet meer stellen (176).

Het is opmerkelijk dat hier ook Kuiterts verzet tegen Barth begint. Bij Barth is de mogelijkheid van de openbaring alleen vanuit haar werkelijkheid te bespreken. God kan volgens Barth alleen door God gekend worden. Verificatie, controle van het openbaringsbegrip is bij Barth niet mogelijk. Het is bij Barth om een latere uitdrukking van Kuitert te gebruiken: stikken of slikken. Bonhoeffer noemde dat: Offenbarungspositivismus bij Barth en daar wil Kuitert niet van weten.

Daarom gaat hij nu welbewust op de Pannenberg tour. Die legde het kriterium voor geloofsuitspraken in het antwoord op de vraag of zij toekomst openen. God machtigt ons volgens Pannenberg ,alle godsdienstige uitspraken erop af te tasten of ze zin bevatten, d.w.z. of ze toekomst ontsluiten dan wel toekomst blokkeren" (203). $\mathrm{Bij}$ die controle kunnen dan ook niet-christenen meedoen. Dat is voor Kuitert een bijzonder belangrijk punt. Daardoor wordt een open dialoog met niet-christenen en aanhangers van andere godsdiensten over de waarde van de christelijke geloofsuitspraken mogelijk. Volgens Kuitert opent Pannenberg zo een derde weg tussen liberaal positivisme in de theologie en de existentietheologie.

Waarom is de Schrift geen maatstaf voor warheid?

Waarom is de Schrift, of de openbaring zo men wil, zelf niet te gebruiken als maatstaf ter controle van de waarheidswaarde van christelijke geloofsuitspraken? We raken hier een uitermate belangrijk punt in Kuiterts redenering, dat van nu af aan een centrale rol bij hem speelt.

Het gaat Kuitert om de kwestie van het gezag, de autoriteit. Hij verzet zich voortdurend tegen de stelling dat God in de Schrift onderwerping van ons vraagt. Geloven is geen kwestie van een sprong, een besluit tot capitulatie voor God, het is een zaak van ervaring en van inzicht. Spreekt God dan niet door de Bijbel en vraagt $\mathrm{Hij}$ dan aan ons geen onderwerping? Deze vraag, aldus Kuitert, „localiseert haarfijn de plaats waar het probleem ligt" (188). Hij antwoord: we krijgen geen stemmen uit de hemel. Openbaring komt tot ons door mensen. „Openbaring”, om hem letterlijk te citeren, ,woord van God, heeft altijd a.h.w. handlangers die namens God - al dan niet terecht — om gehoor en gehoorzaamheid vragen" (189). Kuitert is als de dood zo bang voor een autoritair openbaringsbegrip en daarom wil hij controle laten oefenen op wat handlangers van God als openbaring uitgeven. Daar komt de verstaansvraag nog bij. „Wij ontmoeten in de bijbel de eerste getuigen, die in hun taal en binnen hun horizon hun godservaring en godsgeloof onder woorden brengen." Daarom verhindert de verstaansvraag ons „om van de Schrift een eenvoudig criterium te maken" (187).

Het is duidelijk: de Bijbel als norm en maatstaf van Gods openbaring schuift Kuitert terzijde. Er moet daarom een andere maatstaf komen voor wat openbaring is. Openbaring geschiedt door 
mensen en mensen kunnen niet op hun gezag als handlangers van de openbaring, als openbaringsinstrumenten zegt men in de klassieke theologie, aanvaard worden. Daarom moet de theologie uitmaken wat openbaring is en wat als openbaring kan worden aanvaard.

Kuitert heeft deze gedachtengang verder uitgewerkt in een referaat dat hij op 6 januari 1976 in Lunteren heeft gehouden. De Conerale Synode van de Geref. Kerken (synodaal) kwam op die dag niet als synodevergadering maar als conferentie bijeen om Kuitert en Herman Ridderbos over deze vraagstukken te horen refereren en discussiëren. De referaten zijn gepubliceerd in „Kerkinformatie" van februari/maart 1976 en geven een goed inzicht in de problemen die hier aan de orde zijn. Kuitert had in 1974 een reeks radiolezingen gehouden over het onderwerp ,Zcndcr geloof vaart niemand wel. Een plaatsbepaling van christendom en kerk". Het gelijknamige geschrift waarin hij deze lezingen publiceerde, had veel vragen opgeroepen. Daarom besloot men deze conferentie te houden.

In Stelling IV van dit referaat stelt Kuitert opnieuw: „Openbaring is nict een criterium dat over waar en onwaar van Godskennis beslist. Integendeel, er is een criterium nodig om te kunnen uitmaken of iets openbaring is (van God komt) of niet (van God komt)". Hij licht dat als volgt toe: je kunt ergens niet het etiket op plakken van ,waar" omdat het openbaring is. De andere godsdiensten zeggen dat immers ook van zichzelf. Je kunt je óók niet beroepen op de inspiratie van de Schrift want die theorie heb je zelf bedacht (R.9). De Bijbel zelf is traditie, traditie hoe mensen vroeger God hebben ontdekt," een historische manier van spreken over een aan de historie zelf opgedane ervaring van God (R.9)". Daarom is het soortelijk gezag van de Bijbel alleen traditiegezag.

Nogmaals: de Bijbel wordt dus opzij geschoven als openbaringsnorm en maatstaf voor het geloof. Toch kan ook Kuitert niet zonder een maatstaf. Anders zou iedereen voor openbaring kunnen uitgeven wat hij wilde. Hoe kunnen we tot de scheiding van wat waar en vals is in de openbaring komen? Daar is maar één antwoord op, zegt hij, ,omdat je ervan leeft, omdat je er iets in vindt wat maakt, dat je verder komt vandaag als mens, nergens anders om". Of anders gezegd: „omdat er wat in staat wat je door de jungle van het leven van vandaag heen helpt" (R.10). Dat is die enige manier waarop traditie gezag kan hebben. Je moet er mee uit de voeten komen en de theologie moet wat zich als openbaring uitgeeft, daarop aftasten.

In "Zonder geloof vaart niemand wel" uit 1974 had Kuitert dat al uitgewerkt op een populaire manier. We treffen daarin soortgelijke gedachten en uitspraken aan. Daarin keert Kuitert zich vooral tegen het traditionele christendom. Het staat met het gelaat naar gisteren gekeerd. Het heeft de godsdienstige tradities georganiseerd die autoritair aan de mensen worden opgelegd. Dat was in Paulus' dagen al het geval met de besnijdenis (Z. 51). Daardoor is de kerk een bazige kerk geworden. Secularisatie is dan ook niet anders dan het zich losmaken van de autoriteit van de kerk (Z.59). 
We kennen de christelijke waarheid alleen in de voorstellingswereld van gister waarin zij ons is overgeleverd en wij kunnen haar alleen verder vertellen in de taal van ons hedendaagse voorstellingswereld" (Z. 104). Daarom verandert het leven ook de leer. Kuitert gebruikt hier ook de term van bijstellen die we later vaak bij hem tegenkomen. De christelijke leer moet „bijgesteld worden om in andere nieuwe tijden het heil van God voor mens en wereld weer onder woorden te kunnen brengen" (Z. 107).

Hoezeer hier alles in een zich evoluerende historiciteit begrepen is, blijkt wel als Kuitert opnieuw betoogt dat Gods openbaring „niet anders dan op de wijze van ons eigen spreken over God en zijn openbaring" voorhanden is. Hij trekt daaruit de conclusie: „Gods spreken door het spreken van mensen heen, betekent dus eigenlijk: door het veranderende spreken van mensen heen" (Z. 107). Maar wat is dan het blijvende, het „overschot" in het christelijk geloof waardoor het niet met de cultuur op en neer gaat? Dat overschot antwoordt hij, ,haalt het christendom uit de verhalen over Jezus, die we in het Nieuwe Testament vinden opgetekend" (Z. 108). En weer krijgt de theologie de taak critisch te schiften tussen christelijke geloofsverantwoording, ,die houdbaar en die onhoudbaar is" (Z. 100).

\section{Die opstanding van Christus}

Kuitert doet in „Zonder geloof vaart niemand wel" verreikende uitspraken. Zo zegt hij dat we nauwelijks aan de conclusie kunnen ontkomen ,dat hiernamaals, laatste oordeel, hemel en dergelijke thema's allemaal projecties van mensen zijn over een toekomst waar ze eigenlijk niet van weten. De doden trekken de ladder achter zich op" (Z. 85). Je kunt ze nooit meer bereiken.

Wij geloven echter wel in een toekomst die sterker is dan de dood. In dit verband komt hij dan te spreken over de opstanding van Christus. Terwijl hij die nog in eerdere geschriften buiten kritiek stelde, spreekt hij er thans veel minder concreet over. Christenen spreken over de opstanding van Christus "niet als een willekeurig mirakel" - wie doet dat wel? -, maar als een zinvolle, meer nog als een zinstichtende gebeurtenis aan de gekruiste Jezus. God heeft Hem opgewekt wil voor hen zeggen: God heeft aan Hem gedemonstreerd dat er een macht is die sterker is dan de zinloosheid stichtende dood, en dat is de macht van God zelf en zijn toekomst, die we daarom niet zomaar almacht noemen - almacht is dommekracht - maar heilsmacht van God en zijn toekomst" (Z. 84). De vraag die hier natuurlijk onmiddellijk rijst en niet ten onrechte gezien de ontmythologisering van Christus' opstanding in de theologie van Bultmann is: wat houdt die zinstichtende gebeurtenis aan de gekruiste Jezus nu in? Wat heeft God aan Hem gedemonstreerd? Hoe heeft God aan Hem laten zien dat Hij sterker is dan de dood? Is $\mathrm{Hij}$ werkelijk opgestaan en heeft $\mathrm{Hij}$ de dood overwonnen of leeft Jezus voort in het kerygma van Gods bevrijdende liefde? 
samen te vatten en dat er van $U$ nogal wat wordt gevraagd in dit referaat. Daarom is het goed eens even op dit punt terug te zien voor we tot Kuiterts laatste publicatie komen. Ik zou hier enkele punten willen samenvatten:

1. In zijn publicaties vóór 1970 ging het Kuitert vooral om de vraag hoe de Bijbel moet worden uitgelegd. Met welke boodschap kcmt hij tot ons. In de kwestie van het antropomorfe spreken Gods reikte hij als verstaanssleutel aan: we moeten ons bekeren tot het Israelitisch spreken over God. Je kunt niet scheiden tussen de culturele omkorsting en het eigenlijke spreken over God. Je moet de uitspraken over God letterlijk nemen. Maar in De realiteit van het geloof wilde hij onderscheiden tussen de "Sache", dat is het verhaal omtrent Jezus en de verpakking, de boodschap en de kennisbagage.

2. In Verstaat gij wat gij leest? viel Genesis 1 tot 3 onder de kennisbagage. We moeten het niet schrappen uit de Bijbel maar het zien als een leermodel. Israel brengt daarin tot uitdrukking dat de Verbondspartner-God Heer is over alles en bedient zich daarvoor van materiaal uit de godsdienstgeschiedenis. Dit heeft ook verregaande consequenties voor het spreken over de dood.

3. In zijn geschriften na 1970 werpt Kuitert zich op het openbaringsvraagstuk. God openbaart Zich door mensen. De openbaringsinstrumenten zijn handlangers van God als mensen. God spreekt door hun spreken heen. De theologie krijgt nu volop de taak de waarheid van de openbarings- en geloofsuitspraken te controleren en af te tasten op hun waarheidsgehalte.

4. Dat waarheidsgehalte ligt in het openen van toekomst voor mens en wereld. Je moet ermee uit de voeten kunnen. Als dat niet het geval is, moeten de christelijke geloofsuitspraken worden bijgesteld. Ek zit een ontwikkeling in de openbaring naar de toekomst.

\section{STRUCTUUR VAN DE CHRISTELIJKE GELOOFSUITSPRAKEN}

In 1977 verscheen zijn meest belangrijke publicatie ,Wat heet geloven?" met als ondertitel "Structuur en herkomst van de christelijke geloofsuitspraken". Dit 232 pagina's tellende boek is in zekere zin cen afronding van zijn theologisch denken. Allerlei eerdere motieven komen er in terug en zijn nu in een systematisering verwerkt. Het boek is niet gemakkelijk. Het is wetenschaps-theoretisch opgesteld. Kuitert beroept zich nu veel meer dan in eerdere geschriften op de wetenschapstheoretici, sociologen en godsdienstpsychologen uit de angelsaksische wereld.

Laat ik eerst inzicht geven in de algemene strekking van het boek. Het zet in met als probleemstelling: stikken of slikken. We kwamen die al eerder tegen. Kuitert verzet zich fervent tegen een autoritair openbaringsbegrip en een geloven op autoriteit. Het gaat bij de geloofsuitspraken - proposities noemt Kuitert ze in dit boek - niet om geloven op gezag maar om inzicht en ervaring. Dat zijn de sleutelwoorden waarvan hij zich nu bedient. Waar komen de geloofsproposities vandaan en hoe zitten ze in elkaar? Waar steunen 
ze op? Na de inleiding volgt in zekere zin een drietrapsraket (vuurpijl). Die bestaat uit drie fasen. Eerste fase: die is antropologisch. Kuitert noemt dat geestig: een antropologisch vloertje. Als zodanig dient hij het oergeloof aan. Ieder mens hecft een oergeloof. Dat oergeloof bestaat in het zin-geven en zin-ervaren dat de mens aan de werkelijkheid van de wereld doet. Die wereld is zin, een betekenis verlenend geheel waarop de mens is aangewezen. Dat oergeloof is wel een aangevochten geloof. Wanhoop en vertwijfeling bedreigen de mens. Die idee van het oergeloof doet denken aan de geloofsfunctie uit de Wijsbegeerte der wetsidee. Die heeft volgens deze wijsbegeerte ook ieder mens. Ook het spreken van de werkelijkheid als zin vinden we bij Dooyeweerd. Heeft Kuitert hier leentjebuur gespeeld?

De tweede fase in de raket (vuurpijl) is wat Kuitert noemt het zoekontwerp. Het oergeloof komt $\mathrm{nl}$. in reincultuur nergens voor. De mens heeft het in de loop van de tijd aangekleed met godsdienstige voorstellingen. Godsdienst is een antwoord op de ondoorzichtigheid (dood, lijden enz.) waarop het oergeloof stuk loopt. Doordat de mens God ervaart in natuur en geschiedenis, bouwt hij uit die ervaring een ontwerp van God op. Daarbij bedient de mens zich van wat Kuitert ,interpretatiekaders” noemt. Van ouds heeft de mens zijn ervaringen met God geinterpreteerd. Die verschillende interpretaties hebben zich verdicht tot interpretatiekaders. Ze bestaan uit cumulatieve ervaring, opeengehoopte ervaring. Het christelijk zoekontwerp is tot stand gekomen uit ervaring van Israel met God en de ervaringen rond Jezus. Die vormen de gronden voor het zoekontwerp. Die gronden zijn te toetsen door alle mensen. Hier hebben we weer de controlegedachten uit eerdere publicaties. Het moet bovendien de proef op de som doorstaan. Daarvoor is het dan ook een ontwerp. Pas in de gang van de geschiedenis vindt het zijn bevestiging.

We komen nu tot de laatste fase. Het zoekontwerp is historisch de derde en laatste trap is institutioneel. Ze bestaut uit de leer van de kerk. Het christelijk zoekontwerp ging namelijk al spoedig over in kerkleer, de geloofsproposities. Voor de kerkleer is de Bijbel geen maatstaf of criterium. De Bijbel is er wel de oorsprong van, en met name de eerste getuigen. Binnen deze eerste getuigen is Jezus zelf weer de maatstaf. Hij is de canon binnen de canon. Dat had Kuitert trouwens al in zijn referaat van 1976 gezegd.

Omdat nu het zoekontwerp historisch is en voortdurend moet worden bijgesteld, geldt dat ook van de kerkleer. Daarom mag deze nooit met dwang, autoritair worden opgelegd. Door tolerantie en dialoog komt de kerk tot de enigheid des geloofs waarvan Ef. 4:13 spreekt en die een eschatologisch begrip is.

$\mathrm{Na}$ de afhandeling van deze drietrapsraket wijdt Kuitert dan het laatste en zeker niet onbelangrijkste deel van zijn boek aan de vraag "How do you know?" Daarin gaat hij expliciet in op de vragen wat openbaring is en hoe ze gezag heeft. Dit gedeelte is een felle en geducht geargumenteerde bestrijding van de openbaringsleer van Karl Barth. 


\section{Schrift, openbaring en ervaring}

Ziedaar een doorkijkje van de opbouw van het boek. Ons interesseert nu vooral binnen het kader van dit referaat wat Kuitert als afsluitende gedachten over Schrift en openbaring biedt. Want dat is de kern van zijn theologie. Godsdienst berust bij hem op openbaring, ze is geen projectie of vrucht van fantasie. In par. 9 gaat Kuitert uitvoerig in op wat onder ervaring is te verstaan. Ervaring doet een mens op aan God. Je zou kunnen zeggen: in de ervaring meldt Zich God. Israel deed ervaring op aan God b.v. in de uittocht uit Egypte. De eerste getuigen deden ervaring op aan Jezus. Ervaring vindt dus ,unten”, beneden, plaats aan God die Zich van ,oben”, van boven openbaart. Hoe openbaart God Zich nu? Op dit punt gekomen, verwerpt Kuitert met zoveel woorden het onderscheid tussen algemene en bijzondere openbaring. Dit is een diepe ingreep op de klassieke gereformeerde openbaringsleer, ook in strijd met art. 2 N.G.B. Kuitert krabbelt in een noot op blz. 192 een beetje terug naar aanleiding van kritiek van prof. Runia. Hij zegt in die noot dat hij ook wel wil onderscheiden tussen algemeen en bijzonder bij openbaring, maar dit alleen wil laten slaan op het onderscheid tussen de kennis van God in en door Jezus (die is dan bijzonder) en algemeen is dan de overige Godskennis. Maar hij stelt in die noot wel nadrukkelijk dat hij in geen geval het verschil in modus erkent.

Zowel Gods openbaring in natuur en geschiedenis als die in de Heilige Schrift vallen dus bij Kuitert onder de ene noemer openbaring. En die openbaring van Gold meldt zich in de ervaring. Omdat de Schrift vrucht van ervaring is, is wat geen openbaring behoeft uit te sluiten.

Hoe openbaart God Zich nu? Dat doet $\mathrm{Hij}$ door wat Kuitert in navolging van anderen ,signalen” of ,cues" noemt (142). God geeft in de zichtbare wereld signalen van zijn tegenwoordigheid. Het zijn ,,sporen van God": ze springen uit de gewone wereld en de gewone gang van zaken uit (142). Als zodanig vallen te noemen water, vuur, aarde, sexualiteit en ratio tot historische gebeurtenissen als Israels exodus en Jezus' kruisiging. Let wel: Kuitert noemt hier niet Jezus' opstanding, die is geen historische gebeurtenis. Aan deze sporen van God, deze signalen en cues, ervaart de mens God. Die ervaring verwerkt hij tot zijn zoek-ontwerp. Dat stellen mensen samen met behulp van de interpretatiekaders die gegroeid zijn uit de ervaring van de voorgeslachten. Die interpretatiekaders vormen dus samen het zoekontwerp en dat wordt geconcretiseerd in de christelijke leeruitspraken. Evengoed als nu die interpretatiekaders historisch en veranderbaar zijn, geldt dat ook van de christelijke leer. Ook die moet telkens worden bijgesteld. $Z o$ is het Nieuwe Testament een bijstelling van het Oude. Het laatste geldt alleen voor Israel, het eerste ziet God als heilsgod voor alle mensen. De bijbel zelf is dus een historisch boek en als zodanig staan er veel dingen in die voor ons niet meer terzake zijn omdat ze een andere leefwereld veronderstellen (58).

Samenvattend: God valt niet samen met deze wereld. Hij openbaart Zich in deze wereld door ,sporen" van Hem, signalen, 
cues. Die vangen mensen op, ze ervaren die en spreken zo over God. De mens die in zijn oergeloof behoefte heeft aan zingeven en zinverlening van deze wereld, verwerkt die ervaring door middel van interpretaties die uitgroeien tot zoek-ontwerpen. Deze zoekontwerpen worden geconcretiseerd in is-zinnen. Het christelijk zoekontwerp heeft daarom geloofsuitspraken die door de kerk worden geformuleerd, de fides quae creditur.

Omdat echter Gods openbarende actie voortdurend doorgaat, en mensen steeds weer nieuwe dingen aan God ervaren, moeten de interpretatiekaders van tijd tot tijd worden bijgesteld. Dat brengt met zich mee dat ook de is-zinnen historisch bepaald zijn en de kerk er niet aan binden mag. $\mathrm{Zij}$ moeten evengoed bijgesteld worden. De kerk kan niet buiten is-zinnen. Hun historisch karakter brengt echter mee dat ze in tolerantie en dialoog met haar leden moet omgaan.

De Bijbel heeft in dit historisch proces een eigen plaats. Hij is vrucht van ervaring van vroegere geslachten. Binnen de Bijbel zelf is reeds een bijstellingsproces gaande. Daarom kan ze niet als maatstaf fungeren. Ze is alleen bron voor de christelijke waarheid. Wel houdt vooral het verhaal omtrent Jezus voor de kerk grote waarde. Hij is het vleesgeworden geloven en houdt voortdurend het geloven van de kerk op gang door wat ze aan zijn verhaal ervaart.

Het spreekt vanzelf, zoals ik reeds opmerkte, dat Kuitert in botsing moest komen met Karl Barth. Het laatste gedeelte van zijn boek is een felle bestrijding van Barth. De kern van Barths openbaringsleer is immers die unaufhebbare Subjektivitat Gottes in zijn openbaring. God openbaart Zich als Dei loquentis personax in het Woord Gods, dat in de Bijbel een bepaalde gestalte heeft gekregen. De theologie neemt bij Barth haar uitgangspunt in het spreken Gods, het Woord als „Ereignis”, zonder verder de mogelijkheid van dit spreken te verantwoorden of er kontrole op toe te staan. De werkelijkheid van de openbaring is bij Barth het uitgangspunt voor het spreken over de mogelijkheid van de openbaring. En hier komt bij Kuitert, wat Barth betreft, Leiden in last. Want het ging Kuitert juist om verificatie van de openbaring, al noemt hij die term in zijn laatste boek nauwelijks meer en vervangt hij die door plausibiliteit (59). De traditie, zo betoogt hij nu, dat zijn dus de christelijke geloofsuitspraken, moeten worden getoetst op hun plausibiliteit en dat gebeurt natuurlijk door ,de wetenschappelijke theologie" (59). Daar is bij Barth geen sprake van en dus trekt Kuitert tegen Barth ten strijde. Hij noemt zijn theologie een kolos op lemen voeten (219).

Immers: bij Barth is geen sprake van bemiddeling van de openbaring door mensen die God ervaren en die die ervaring interpreteren. God openbaart Zich direct. Wanneer mensen „bemiddelend", interpreterend over God spreken, zijn zij te controleren. In openbaring spreken volgens Kuitert mensen over God. Maar bij Barth spreekt God Zelf, zij het als „Ereigenis”, door de Bijbel heen en wie zal God controleren? God openbaart Zich niet bij Barth door onze historische leefwereld, niet in en door de 
geschiedenis en daarom onttrekt zijn openbaring zich aan redelijke kritiek en inzicht. En juist die bestaande wereld wil Kuitert zien als een ,vlechtwerk van Gods daden" waarin een keer het gezicht van God voor alle mensen zal oplichten (229). Daarom kan de christelijke kerk ook hopen „,dat haar ontwerp van God uiteindelijk door de ervaring zal bevestigd worden, dat wil zeggen: "dat God Zich eenmaal definitief onthullen zal, en dan zoals Jezus Hem ons hecft uitgelegd: als universele, alle mensen vrijheid schenkende liefde" (230).

Aan het slot van zijn boek gekomen, verwerpt Kuitert nogmaals het supranaturele openbaringsbegrip, hij noemt dat „inbraak" in onze wereld. God openbaart Zich alleen en altijd bemiddelend door natuur en geschiedenis en dus ook dat ligt daarin opgesloten - door wat mensen doen, denken en nalaten" (231).

Zo komt hij tot zijn conclusie dat de vraag „How do you know?" het beste beantwoordt wordt te verwijzen "naar de cumulatieve menselijke ervaring". Dat schept ruimte ,voor toetsing en verantwoording van het christelijk geloof, en daarmede ruimte voor de communicatie tussen christenen en niet-christenen". De zaak van de controle van de geloofsuitspraken weegt Kuitert zo zwaar dat hij er zijn meest indringende boek mee besluit.

\section{DE HERMENEUTISCHE VRAAG BIJ KUITERT 1962-1977}

Het was een lange weg van de Mensvormigheid Gods in 1962 naar "Wat is geloven?" in 1977. Maar het ging al die jaren om de vraag hoe de Bijbel als boodschap Gods overkomt tot de mens van deze tijd. Het ging om de hermeneuse. Kuitert heeft op zijn manier de uildaging van Bultmanns ontmythologiseringsprogramma aanvaard. Hoe kan Gods boodschap overkomen tot mensen die in de door de natuurwetenschappen beheerste leefwereld leven? Bultmann wilde daartoe de Bijbel, het evangelie laten spreken tot de door zijn existentialiteit bepaalde mens. De boodschap van de Bijbel spreekt de moderne mens aan op zijn existentie, schenkt hem vrijheid en vergeving. Bevrijdt hem van zijn schuldig verleden. Die boodschap klinkt bij Bultmann door middel van kritiseerbaar mythologisch materiaal. Kuitert heeft terecht erop gewezen, dat zo bij Bultmann het „Vorverständnis" van de mens vanuit de existentiefilosofie als filter fungeert voor de bijbelse boodschap.

Maar hoe heeft hij het er zelf afgebracht? Het begon met zijn proeve inzake het mensvormig spreken Gods. Dat vertolkte hij niet vanuit de transcendentie Gods zoals de klassieke gereformeerde theologie altijd deed: als God zijn oor neigt wordt dat oor uitgelegd vanuit God die ermee hoort, Goddelijk. Nee, wij moesten dat nemen als Israelitisch spreken over God. En de theologie moet ons helpen dat te verstaan. Daarna ontwierp Kuitert zijn volgende project in "De realiteit van het geloof". Nu werd ,historisch" het sleutelwoord: het Schriftgetuigenis is een historisch traditum, de Bijbel komt tot ons in een historische doorgeef- en toeeigeninggestalte. Historisch staat bij Kuitert steeds voor veranderbaar, tijdelijk, vatbaar voor veroudering, in geen geval voor betrouwbaar. 
Het Schriftgetuigenis werd nu opgedeeld in een brutogetuigenis waarvan „die Sache”, Jezus, het netto is en de rest verpakkingsmateriaal.

Eenmaal op dat punt aangekomen, werden de eerste grondleggende hoofdstukkn van de Bijbel, de protologie tot verpakkingsmateriaal gedegradeerd. Ze zijn interpretatie van godsdiensthistorisch materiaal van de andere volkeren vanuit het geloof dat Israels Bondsgod ook Schepper is, Heer van de geschiedenis. Maar zijn ze nu juist of niet? Die vraag heeft G. Visee terecht gesteld in een grondige bespreking van Kuiterts „Verstaat gij wat gij leest?” En als ze onjuist zijn, waarom ze dan niet uit de Bijbel gescheurd? Ze kunnen dan ook niet fungeren als kennisbagage, want ze verschaffen gewoon geen betrouwbare kennis. Maar waar komen ze dan wel vandaan? Zo als ze in de Bijbel staan, zijn ze bij geen enkele andere godsdienst te vinden. Is er dan toch natuurlijke theologie vraagt Visee terecht? En wat de „Sache” betreft, Kuitert concentreert zich tot op zijn laatste boek daarvoor op Jezus. Maar welke Jezus? Ook hier stelt Visee terecht vragen: De Jezus van de Bijbel, de gekruiste opgestane en voor onze zonclen gestorven Jezus?

Dr. W. H. Velema noemde zijn studie over Kuiterts theologie „Aangepaste theologie". Hij bedoelt daarmee dat Kuitert zijn theologie heeft aangepast aan het moderne levensgevoel (173). Ik vond dat niet de meest gelukkige karakterisering. Wat is het moderne levensgevoel? Hoever reikt dat? Kuitert houdt vast aan het geloof in God, hoe hij dat ook verder moge omschrijven. Hoort God bij het moderne levensgevoel? Het gaat Kuitert om de hermeneuse, de vertolking voor de moderne mens. Hij past zijn theologie niet bij die moderne mens aan maar hij wil die moderne mens mee laten spreken over het christelijk geloof. Hij moet de christelijke geloofsuitspraken kunnen controleren op hun redelijkheid en inzichtelijkheid, en met zijn eigen ervaring van de wereld.

Dr. S. Meijers heeft in zijn omvangrijke dissertatie uit 1979 „Objectiviteit en existentie” ook aandacht aan Kuitert geschonken. Hij heeft er enkele rake opmerkingen over gemaakt. Zo schrijft hij dat Kuitert, evenals Van Ruler, theologiseert „tegen de achtergrond van de crisis van het autoriteitsbeginsel. Beiden trachten zij de opdringende scepsis ten aanzien van Gods openbaring te overwinnen". Kuitert doet dat door de zekerheid in de personaliteit en zijn ervaring te stellen" (380). Zijn eigenlijke interesse geldt de hermeneuse ,en niet de verwerking van de inhoud van de openbaring" (397).

Het gaat om de zekerheid van de is-zinnen van het christelijk geloof, ten diepste om de juistheid van het ter sprake brengen van God. Kuiterts theologie is niet in de eerste plaats een theologie van de geschiedenis zoals M. P. van Dijk in "Kerk en theologie" schrijft, hoezeer hij ook rake kritiek oefent. Het is ten diepste apologetische theologie. Kuitert wil het christelijk geloof in God inzichtelijk en bespreekbaar maken voor de niet gelovige moderne mens. Hij handhaaft het klassieke gereformeerde uitgangspunt dat God Zich van boven openbaart maar daarna neemt hij dan ook 
grondig afscheid van die klassieke theologie. Meijers formuleert het zo: „Bij Kuitert staat tegenover de applicatio salutis (de toeeigening des heils) de verificatiegedachte. De theologie moet door haar wetenschappelijke controle van de openbaring het geloof veilig stellen en verdedigen. $\mathrm{Zij}$ tast de traditie en de ervaring af op haar houdbaarheid en zij decreteert of de christelijke is-zinnen moeten worden bijgesteld."

Kuitert handhaaft dat God zich beneden van bovenaf openbaart maar Gods openbaring vindt plaats in het voortgaande proces van de geschiedenis waarin de mensen die over God spreken zijn opgenomen. God valt niet samen met de werkelijkheid, dat wel. Maar onze kennis aangaande Hem groeit mee met de ontwikkeling van de geschiedenis en zal eenmaal in het eschaton haar volheid bereiken. Is dat eschaton inbreuk op de bestaande wereld, vernieuwing en herschepping van boven of alleen uitgroei tot een universele mensheid met een universele godskennis? Kuitert laat de mens ook meegroeien met de geschiedenis. Hij wijst de evolutieleer niet principieel af. Integendeel, hij schrijft ergens dat wat de mens maakt het beeld Gods is, maar dat is iets anders dan dat God de mens schiep naar zijn beeld. Wie de protologie loslaat, laat ook de bijbelse eschatologie los.

Kuitert verwerpt het onderscheid tussen algemene en bijzondere openbaring. De Bijbel is vrucht van ervaring van mensen die over God spreken vanuit die ervaring. $\mathrm{Zij}$ is bron, geen maatstaf. Maar wat is nu bij hem openbaring? Openbaring van God door signalen van God, door cues meldt zich in de ervaring. Ze is, dat heeft terecht Meijers opgemerkt, ,geen werkelijkheid buiten ons zelf die gezag hebbend van buiten de geschiedenis op ons aankomt. God poneert noch Zichzelf, noch Zijn openbring, noch Zijn heil" (335). $\mathrm{Ze}$ is in geen geval Woordopenbaring. God spreekt niet tot ons door apostelen en profeten. De Heilige Schrift is niet het spreken tot ons door middel van de openbaringsinstrumenten van wie hun bemiddelend spreken over God in de Schrift betrouwbaar is vastgelegd.

De klassieke gereformeerde theologie heeft terecht gestaan en staat vandaag nog voor de eenheid van de Schrift. Jezus is geen canon in de canon. Hij is wel de in het Oude Testament beloofde en in het Nieuwe Testament gekomen Messias, die tot ons komt in het gewaad van de Schrift. Sinds de Pinksterdag bedient God de Heilige Geest Zich van de Schrift om het heil in Christus naar ons toe te dragen. Applicatio salutis betekent dat de Heilige Geest van deze Schrift naar haar inhoud en met haar inhoud het gezaghebbende woord van God is. Terecht heeft Buytendach in zijn dissertatie krachtig vastgehouden aan de eenheid van vorm en inhoud van de Schriften.

Moet de gemeente afhankelijk worden van de wetenschappelijke theologie voor haar geloof in de Christus van Oude en Nieuwe Testament? Kuitert tobt met de Schrift en haar spreken en hij zoekt zelf de oplossing voor zijn moeite in de theologie. Het is een lange wetenschappelijke weg waardoor hij komt tot de structuur en de aanvaardbaarheid van de christelijke is-zinnen, van de 
geloofsuitspraken. De Gereformeerde Kerk heeft in haar confessies geloofsuitspraken gedaan, en ze verantwoord uit de Schrift. Ze zijn niet opgenomen in een historisch proces van steeds bijgestelde interpretatiekaders maar rusten in het spreken van God in Christus in de Bijbel. De Gereformeerde Kerk heeft wel de mogelijkheid geschapen ze bij te stellen indien ze niet met de Schrift overeenstemmen. Ze heeft daarvoor de weg van het gravamen vanuit de Schrift geopend. Dat is geen gemakkelijke weg. Maar indien nodig, dan zal de kerk daarover oordelen. De theologie kan daar hulpdiensten bij verrichten maar de kerk zelf beslist hierover. De gemeente Gods is een vrije mondige gemeente, dat zijn we met Kuitert eens. Maar dat betekent dat zij zichzelf bindt in vrijheid aan de in geloof verstane Schriften, niet aan de telkens veranderende uitspraken van de theologie.

Als we overzien wat van centrale geloofsinhouden die de kerk in de tijd van de reformatie beleden heeft, in Kuiterts theologie is terecht gekomen, dan staan we voor een ruïneveld. Het zij de gereformeerde theologie gegeven, in geduld dit puin te ruimen en haar huis te blijven bouwen vanuit de Heilige Schrift en de klassieke confessies van de kerk in blijvende zelfbinding aan Gods gesproken Woordopenbaring.

Voordrag gelewer voor G.T.V. Potchefstroom, 14 April 1980. 